Brazilian Journal

of Chemical

Engineering

\title{
SYNTHESIS AND CHARACTERIZATION OF FRUCTOSYLTRANSFERASE FROM Aspergillus oryzae IPT-301 FOR HIGH FRUCTOOLIGOSACCHARIDES PRODUCTION
}

\author{
Josivan S. Cunha ${ }^{1}$, Cristiane A. Ottoni ${ }^{2,3}$, Sergio A.V. Morales ${ }^{1}$, Elda S. Silva ${ }^{3,4}$, \\ Alfredo E. Maiorano ${ }^{3}$ and Rafael F. Perna ${ }^{1 *}$ \\ ${ }^{1}$ Universidade Federal de Alfenas, Instituto de Ciência e Tecnologia, Poços de Caldas, MG, Brasil. ORCID: 0000-0001-5490-875X; \\ ORCID: 0000-0002-2513-8490; E-mail: rafael.perna@unifal-mg.edu.br, ORCID: 0000-0003-3195-8898 \\ ${ }^{2}$ Universidade Estadual Paulista, Instituto de Biociências, São Vicente, SP, Brasil. ORCID: 0000-0003-4069-509X \\ ${ }^{3}$ Instituto de Pesquisas Tecnológicas, Centro de Bionanomanufatura, São Paulo, SP, Brasil. \\ ORCID: 0000-0001-8258-9936; ORCID: 0000-0001-6370-701X \\ ${ }^{4}$ Universidade do Minho, Centro de Engenharia Biológica, Braga, Portugal.
}

(Submitted: November 30, 2018 ; Revised: February 5, 2019 ; Accepted: February 20, 2019)

\begin{abstract}
Fructooligosaccharides (FOS) are mainly produced by microbial fructosyltransferases (FTase, E.C.2.4.1.9), and Aspergillus oryzae IPT-301 has shown high fructosyl transferring and low hydrolytic activities, which leads to high FOS production yields, but the main operating parameters for its best performance have been scarcely studied. Thus, this work aimed to evaluate the cellular growth, production and characterization of mycelial and extracellular FTases by Aspergillus oryzae IPT-301. Experimental design showed that the extracellular FTase performance was optimized (high transfructosylation activity and low hydrolytic activity) for reaction $\mathrm{pH} 5.5$ - 6.75 and temperature of $45-50{ }^{\circ} \mathrm{C}$ and was fitted by the Michaelis-Menten model, while the mycelial FTase showed better performance at $\mathrm{pH}$ below 6.5 and temperature above $46{ }^{\circ} \mathrm{C}$ and was better fitted by the Hill model. The results obtained showed that the fungus represents a promising source for FOS production on a laboratorial scale.
\end{abstract}

Keywords: Aspergillus oryzae IPT-301; Submerged fermentation; Fructosyltransferase; Enzymatic characterization; Fructooligosaccharides.

\section{INTRODUCTION}

Nowadays, there is a continuous and growing attention for dietary prebiotics-oligosaccharides (PO), mainly due to their proven beneficial effects on human and animal health. Among the different PO described in the literature, fructooligosaccharides (FOS) have been described as an important food ingredient due to their excellent nutrition- and health-relevant properties, including low calorie, non-cariogenicity, ability to stimulate the growth of beneficial colonic lactic acid bacteria and to enhance the intestinal immune response, reduction of total serum cholesterol levels, as well as enhancement of calcium absorption (Jitonnom et al., 2018; Zhang et al., 2017).

In nature, FOS can be found in different plants such as onion, garlic, banana, Jerusalem artichoke and some grasses (Maiorano et al., 2008). However, their commercial production is predominantly based on microbial extracellular/mycelial enzymes called fructosyltransferases (FTases EC.2.4.1.9) (MuñizMárquez et al., 2016) in the presence of sucrose. Various FOS synthesized from sucrose include 1-kestose (GF2), nystose (GF3), and $1 \mathrm{~F}$ - $\beta$-fructofuranosylnystose (GF4) where 1-3 units of fructose are attached via $\beta$-(2-1) linkage to the sucrose (Hernández et al., 2017;

*Corresponding author: Rafael F. Perna - E-mail: rafael.perna@unifal-mg.edu.br 
Gujar et al., 2018). These enzymes possess both transfructosylating and hydrolytic activities (Huang et al., 2016). The ratio between transfructosylation and hydrolytic activities $\left(\mathrm{A}_{\mathrm{t}} / \mathrm{A}_{\mathrm{h}}\right)$ can be considered as the most important criteria when evaluating FOS production from different microbial enzymes. When high ratio values $\left(\mathrm{A}_{\mathrm{t}} / \mathrm{A}_{\mathrm{h}}\right)$ are obtained, FTase exhibits greater transfructosylation activity in the reaction medium. Therefore, high transfructosylation activity allows a high conversion of sucrose to FOS, while a high $\left(\mathrm{A}_{t} / \mathrm{A}_{\mathrm{h}}\right)$ is required to avoid the FOS molecule hydrolysis (Hidaka et al.,1988; Cuervo-Fernandez et al. 2004; Cuervo-Fernandez et al. 2007).

Several filamentous fungal strains belonging to the Aspergillus, Penicillum and Fusarium genera have been reported to be producers of these FOS producing or FTase enzymes (Lateef et al., 2008; Lateet et al., 2012; Guo et al., 2016; Ademakinwa et al., 2017; Mano et al., 2018). Many efforts are devoted to optimize nutritional and culture parameters of fermentation processes or genetic alterations to increase enzyme yield and FOS productivity (Ademakinwa et al., 2017; Ganaie et al., 2017; Zhang et al., 2017). Lateef et al. (2012) reported the performance of FTase production by Aspergillus niger using agroindustrial rejects as support (ripe banana peel and cola nut pod), supplemented with yeast extract and sucrose, fermented in shake flasks (30 $\pm 2{ }^{\circ} \mathrm{C}, 144$ hours), obtaining values up to 27.77 $\mathrm{U} \mathrm{g}^{-1}$, demonstrating the potential use of rejects as a culture medium for the production of FTase.

They are mainly composed of kestose (GF2), nystose (GF3), and fructosylnystose (GF4). FOS can be produced by the fructosyltransferase (EC 2.4.1.9) or $\beta$-fructofuranosidase (FFase; EC 3.2.1.26) having a transfructosylating activity. FFase catalyzes both hydrolytic and a fructosyltransferase activities; however, the latter is evidenced only under high sucrose concentrations [3]. It cleaves the $\beta-1,2$ linkage of sucrose and transfers the fructosyl group leading to a FOS formation. Efforts are being made to explore the nature of these prebiotics and to identify microorganisms that produce FFase with a desired stability and suitable activity for industrial use. They are mainly composed of kestose (GF2), nystose (GF3), and fructosylnystose (GF4). FOS can be produced by the fructosyltransferase (EC 2.4.1.9) or $\beta$-fructofuranosidase (FFase; EC 3.2.1.26) having a transfructosylating activity. FFase catalyzes both hydrolytic and a fructosyltransferase activities; however, the latter is evidenced only under high sucrose concentrations [3]. It cleaves the $\beta-1,2$ linkage of sucrose and transfers the fructosyl group leading to a FOS formation. Efforts are being made to explore the nature of these prebiotics and to identify microorganisms that produce FFase with a desired stability and suitable activity for industrial use
Nascimento et al. (2016) utilized Penicillium citreonigrum URM 4459 and applied response surface methodology in shake flasks to determine the fermentation conditions $\left(25.5^{\circ} \mathrm{C}, 67.8 \mathrm{~h}\right.$ and $\mathrm{pH}$ $6.5)$ that maximize the FTase production obtained, detecting the maximal yield of $301.84 \mathrm{U} \mathrm{mL}^{-1}$. Farid et al. (2015) evaluated the influence of medium composition and cultivation parameters on FTase production by Penicillium aurantiogriseum AUMC 5605 in shake flasks. The maximum FTase enzyme activity was produced at initial cultivation $\mathrm{pH}$ values ranging from 6.0-6.5, at an agitation speed of $200 \mathrm{rpm}$ and using vegetative fungal cells as inoculum in the presence of the optimized media. Recently, Nobre et al. (2018) established by experimental design the optimal fermentation conditions $\left(37{ }^{\circ} \mathrm{C}, \mathrm{pH}\right.$ 6.2) to produce FOS from Aspergillus ibericus MUM 03.49. In a bioreactor operated in a one stage process, using the whole cells of the microorganism FOS production reached $0.64 \pm 0.02 \mathrm{~g}_{\mathrm{FOS}} \cdot \mathrm{g}_{\text {initial sucrose }}{ }^{-1}$.

In our previous group experiments (CuervoFernandez et al., 2007; Maiorano et al., 2009; Ottoni et al., 2012) the FTase produced by Aspergillus oryzae IPT-301 presented high transfructosylation activities when concentrated sucrose solutions were used as substrate, which consequently led to high production of FOS. Despite its excellent performance, there is no previous research in the literature which aimed to study the influence of the reaction media temperature, $\mathrm{pH}$ and sucrose concentration on Aspergillus oryzae IPT-301 FTase. The present study focused on laboratory-scale production of Aspergillus oryzae IPT-301 extracellular and mycelial FTases by submerged fermentation using synthetic culture medium and characterization studies of the process parameters (thermal and $\mathrm{pH}$ stability, temperature, $\mathrm{pH}$ and concentration of sucrose from the reaction medium) and on enzymatic kinetic parameter determination.

\section{MATERIALS AND METHODS}

\section{Chemicals}

All chemicals used were of analytical grade. Yeast extract, sucrose, $\mathrm{KH}_{2} \mathrm{PO}_{4}, \mathrm{MnCl}_{2} \cdot 4 \mathrm{H}_{2} \mathrm{O}, \mathrm{FeSO}_{4} \cdot 7 \mathrm{H}_{2} \mathrm{O}$ were purchased from Labsynth ${ }^{\circledR}$ (Diadema, Brazil). Glycerin and phenol were obtained from Isofar ${ }^{\circledR}$ (Duque de Caxias, Brazil). Glucose, $\mathrm{NaNO}_{3}, \mathrm{MgSO}_{4} \cdot 7 \mathrm{H}_{2} \mathrm{O}$, $\mathrm{NaOH}, \mathrm{Na}_{2} \mathrm{~S}_{2} \mathrm{O}_{5}, \mathrm{C}_{7} \mathrm{H}_{4} \mathrm{~N}_{2} \mathrm{O}_{7}$ and $\mathrm{KNaC}_{4} \mathrm{H}_{4} \mathrm{O}_{6} \cdot 4 \mathrm{H}_{2} \mathrm{O}$ were from Dinamica ${ }^{\circledR}$ (Diadema, Brazil). Dextrose Potato Agar was obtained from Kasvi® (São José dos Pinhais, Brazil) and the enzymatic kit GOD-PAP for glucose determination from Laborlab ${ }^{\circledR}$ (Campinas, Brazil).

\section{Microorganisms and culture conditions}

Aspergillus oryzae IPT-301 strain was obtained from the Institute for Technological Research (IPT/ 
SP). The strain was grown on solid media containing (in $\% \mathrm{w} / \mathrm{v}$ ): glycerin 2.5 , glucose 2.5 , dextrose potato agar 2.0 and yeast extract 0.5 , at $30^{\circ} \mathrm{C}$ for 7 days. Spore solution was preparared in glycerol $20 \%(\mathrm{w} / \mathrm{v})$ and ajusted for $10^{7}$ spores $\mathrm{mL}^{-1}$. The spore suspension was mantained in a freezer at around $-12{ }^{\circ} \mathrm{C}$.

\section{Extracellular and mycelial enzyme production}

The microbial growth and standard enzyme production was carried out in $250 \mathrm{~mL}$ unbaffled Erlenmeyer flasks containing $50 \mathrm{~mL}$ of culture medium, with the following composition (in $\% \mathrm{w} / \mathrm{v}$ ): sucrose 15.0, yeast extract $0.5, \mathrm{NaNO}_{3} 0.5, \mathrm{KH}_{2} \mathrm{PO}_{4} 0.2$, $\mathrm{MgSO}_{4} .7 \mathrm{H}_{2} \mathrm{O} 0.05, \mathrm{MnCl}_{2} .4 \mathrm{H}_{2} \mathrm{O} 0.03$ e $\mathrm{FeSO}_{4} \cdot 7 \mathrm{H}_{2} \mathrm{O}$ 0.001 . The $\mathrm{pH}$ of the medium was adjusted to 5.5 before sterilization.

Flasks were inoculated with $0.5 \mathrm{~mL}$ of $10^{7}$ spores $\mathrm{mL}^{-1}$ suspension previously prepared and incubated in rotatory shaker at $30^{\circ} \mathrm{C}$ and $200 \mathrm{rpm}$ for $76 \mathrm{~h}$. Samples for analysis were colleted in predetermined periods until $76 \mathrm{~h}$ and filtered using filter paper (Whatman $\mathrm{N}^{\circ}$ 1). In the filtered broth, $\mathrm{pH}$ and extracellular fructosyltransferase (FTase) activity were measured.

Mycelial FTase activity were determinated with the wet cell pellet formed and the biomass concentration was determined by dry cell weight per volume $\left(\mathrm{g} \mathrm{L}^{-1}\right)$ (Perna et al., 2018). After filtration, using distilled water, the biomass was washed and dried at $60{ }^{\circ} \mathrm{C}$ for $24 \mathrm{~h}$. In predetermined periods, broth was filtered and the $\mathrm{pH}$ values were measured with a digital $\mathrm{pHmeter}$ and the fructosyltransferase activities were determined as described below. The experiments were conduted in triplicate.

\section{Analytical methods \\ Standard enzymatic activity assay}

The enzymatic activities were determinated as follows: $0.1 \mathrm{~mL}$ of suitably diluted supernatant (extracellular FTase) or $0.05 \mathrm{~g}$ of wet mycelium (mycelial FTase) was mixed with $3.7 \mathrm{~mL}$ of $47.06 \%$ $(\mathrm{w} / \mathrm{v})$ sucrose solution and $1.2 \mathrm{~mL}$ tris-acetate buffer $0.2 \mathrm{~mol} \mathrm{~L}^{-1}$ at $\mathrm{pH}$ 5.5. The reaction was carried out in a shaking waterbath at $50{ }^{\circ} \mathrm{C}, 190 \mathrm{rpm}$ for $60 \mathrm{~min}$ and stopped by boiling for $10 \mathrm{~min}$ (Cuervo-Fernandez et al., 2004). The units of transfructosylation ( $\left.A_{t}\right)$ and hydrolytic $\left(\mathrm{A}_{\mathrm{h}}\right)$ activities were defined as the amount of enzyme that transfers a micromole of fructose or releases a micromole of fructose, respectively, per minute under the chosen experimental conditions.

\section{Carbohydrate analysis}

Glucose concentration $(\mathrm{G})$ and reducing sugars (R) were estimated by an enzymatic kit Glucose (GOD/ PAP) method and the 3,5-dinitrosalicylic acid (DNS) method (Miller, 1959), respectively. The concentrations of both fructose $(\mathrm{F})$ and transferred fructose $\left(\mathrm{F}_{\mathrm{T}}\right)$ in the reaction medium were computed using Equations (1) and (2) (Chen and Liu, 1996).

$$
\begin{aligned}
& {[\mathrm{F}]=[\mathrm{R}]-[\mathrm{G}]} \\
& {\left[\mathrm{F}_{\mathrm{T}}\right]=[\mathrm{G}]-[\mathrm{F}]}
\end{aligned}
$$

\section{Characterization of extracellular and mycelial enzymes \\ Thermal and $\mathrm{pH}$ stability on enzymatic activity}

The thermal and $\mathrm{pH}$ stability of the reaction media in activities of fructosyltransferase was investigated. Regarding the thermal stability, $0.1 \mathrm{~mL}$ of suitably diluted supernatant (extracellular FTase) or $0.05 \mathrm{~g}$ of wet mycelium (mycelial FTase) was incubated across a broad temperature range $\left(30{ }^{\circ} \mathrm{C}-65^{\circ} \mathrm{C}\right)$ at $\mathrm{pH} 5.5$ for $1 \mathrm{~h}$, and residual activity was assayed under standard conditions. The $\mathrm{pH}$ stability was determined by incubating $0.1 \mathrm{~mL}$ of suitably diluted supernatant (extracellular FTase) or $0.05 \mathrm{~g}$ of wet mycelium (mycelial FTase) samples in tris-acetate buffer 0.2 mol L-1 $(\mathrm{pH}$ range of $3.0-8.0)$ at $4{ }^{\circ} \mathrm{C}$, for $24 \mathrm{~h}$, and then the residual activity was measured under standard conditions (item 2.4.1).

\section{Effects of sucrose concentration in the reaction media and determination of kinetic parameters}

Enzymatic activities were determined with $0.1 \mathrm{~mL}$ of suitably diluted supernatant (extracellular FTase) or $0.05 \mathrm{~g}$ of wet mycelium (mycelial FTase) with 3.7 $\mathrm{mL}$ of sucrose solution at different concentrations (78.0, 148.0, 296.0, 370.0, 470.6 and $\left.592.0 \mathrm{~g} \mathrm{~L}^{-1}\right)$ and $1.2 \mathrm{~mL}$ tris-acetate buffer $0.2 \mathrm{~mol} \mathrm{~L}^{-1}$ at $\mathrm{pH} 5.5$. The reaction was performed as described above. For enzymatic kinetics evaluation, the sets of experimental data obtained for the transfructosylation activities $\left(A_{t}\right)$ were fitted to the Michaelis-Menten model and the Hill model. Kinetic parameters such as maximum reaction rate $\left(V_{m a x}\right)$ and Michaelis constant $\left(K_{m}\right)$, and Hill constant $(n)$ were obtained using a nonlinear regression analysis performed with the OriginLab ${ }^{\circledR}$ version 8.0 software.

\section{Experimental design and statitical analysis}

The experimental design was obtained employing the software STATISTICA ${ }^{\circledR}$ version 12.0 (StatSoft. Inc. 2007, USA). A full $2^{2}$ factorial design with three assays at the center point was chosen for the study of two factors: $\mathrm{pH}$ and temperature of reactional media, each at five levels. Star points were added to the experimental design to compose a second-order model (Table 1). The data factors were chosen after a series of preliminary assays.

The statistical analaysis of the data was carried out using STATISTICA ${ }^{\circledR}$ version 12.0 (StatSoft. Inc. 
Table 1. Experimental design matrix.

\begin{tabular}{ccccc}
\hline \multirow{2}{*}{ Runs } & \multicolumn{2}{c}{ Coded values } & \multicolumn{2}{c}{ Actual values } \\
\cline { 2 - 5 } & Temperature & $\mathbf{p H}$ & Temperature $\left({ }^{\circ} \mathbf{C}\right)$ & $\mathbf{p H}$ \\
\hline 1 & 1 & 1 & 50 & 8.0 \\
2 & 1 & -1 & 50 & 5.5 \\
3 & -1 & -1 & 40 & 5.5 \\
4 & -1 & 1 & 40 & 8.0 \\
5 & -1.414 & 0 & 38 & 6.75 \\
6 & 1.414 & 0 & 52 & 6.75 \\
7 & 0 & -1.414 & 45 & 5.00 \\
8 & 0 & 1.414 & 45 & 8.50 \\
9 & 0 & 0 & 45 & 6.75 \\
10 & 0 & 0 & 45 & 6.75 \\
11 & 0 & 0 & 45 & 6.75 \\
\hline
\end{tabular}

2007, USA). The response surface model was fitted to two response variables, Y, namely transfructosylation and hydrolytic activities for extracellular (in $\mathrm{U} \mathrm{mL}^{-1}$ ) and mycelial (in $\mathrm{U} \mathrm{g}^{-1}$ ) FTases. The enzymatic activity assay were carried out as decribed above. The second order response functions for two factors are given in Equation (3) and the differences were considered significant at $\mathrm{p}$-values $\leq 0.05$.

$\mathrm{Y}=\beta_{0}+\beta_{1} \mathrm{~A}+\beta_{2} \mathrm{~B}+\beta_{12} \mathrm{AB}+\beta_{11} \mathrm{~A}^{2}+\beta_{22} \mathrm{~B}^{2}$

where $\mathrm{A}$ and $\mathrm{B}$ represent the levels of the factors temperature $\left({ }^{\circ} \mathrm{C}\right)$ and $\mathrm{pH}$, respectively, while $\beta_{0}, \beta_{1}, \beta_{2}$, $\beta_{12}, \beta_{11}$ and $\beta_{22}$ represent the estimated coefficients with $\beta_{0}$ having the role of the offset term.

\section{RESULTS AND DISCUSSION}

\section{Influence of cell growth and enzymatic activity}

Figure 1 shows the growth profile of Aspergillus oryzae IPT 301; the peak biomass concentration, $9.35 \pm 1.26 \mathrm{gL}^{-1}$, occurred in $48 \mathrm{~h}$ of fermentation. In

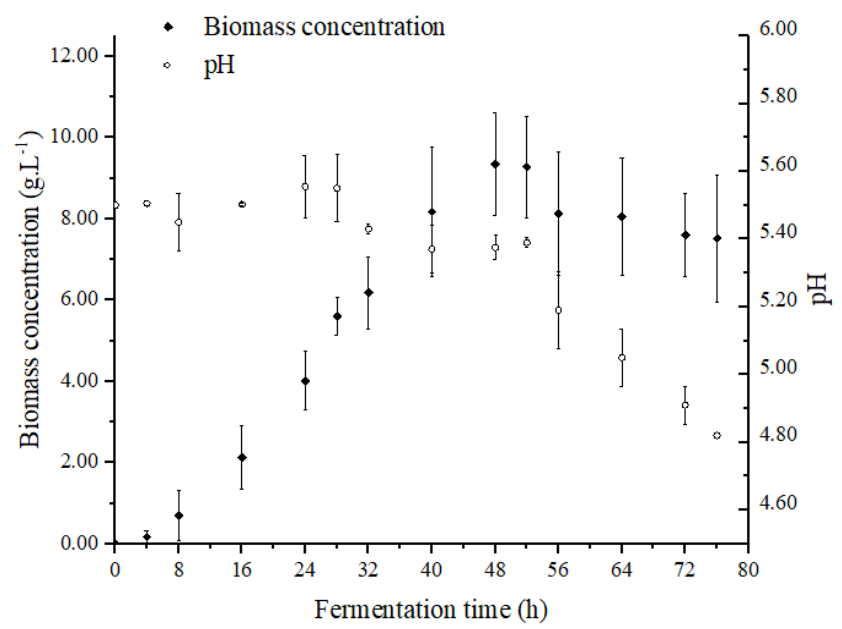

Figure 1. Concentration of the cellular biomass of Aspergillus oryzae IPT-301 and $\mathrm{pH}$ progression as a function of fermentation time. Experimental conditions: spores suspension $10^{7}$ spores per $\mathrm{mL}$, synthetic culture medium, $200 \mathrm{rpm}$ and $30^{\circ} \mathrm{C}$. addition, acidification of the culture medium from $\mathrm{pH}$ 5.50 to 4.82 occurred between $48 \mathrm{~h}$ and $72 \mathrm{~h}$ of the process.

The extracellular transfructosylation $\left(\mathrm{A}_{t}\right)$ and hydrolytic $\left(\mathrm{A}_{\mathrm{h}}\right)$ activities as a function of fermentation time are set forth in Figure 2A. The maximum production of the enzyme FTase, $19.76 \pm 0.56 \mathrm{U} \mathrm{mL}^{-1}$, occurred in $64 \mathrm{~h}$ of fermentation. At the same time, a low $\mathrm{A}_{\mathrm{h}}\left(1.65 \pm 0.31 \mathrm{U} \mathrm{mL}^{-1}\right)$ was detected and the best ratio was $12.22 \pm 1.82$ between $A_{t} / A_{h}$. The highest activity obtained in mycelium (Figure 2B), $\mathrm{A}_{t}(524.55$ $\left.\pm 177.10 \mathrm{U} \mathrm{g}^{-1}\right)$ and $\mathrm{A}_{\mathrm{h}}\left(141.07 \pm 53.12 \mathrm{U} \mathrm{g}^{-1}\right)$ were determined in $72 \mathrm{~h}$ of fermentation. However, the best $8.73 \pm 2.02\left(\mathrm{~A}_{\mathrm{t}} / \mathrm{A}_{\mathrm{h}}\right)$ ratio occurred in $48 \mathrm{~h}$, whereas in $72 \mathrm{~h}$, the value of this ratio was $3.82 \pm 0.67$.

According to Maiorano et al. (2009), the maximum production of FTase using A. oryzae IPT-301 occurred in the range of $\mathrm{pH} 4.5$ to 5.0 , while the maximum biomass production was verified for fermented broths with $\mathrm{pH}$ 5.0. A. oryzae IPT 301 is a producer of acid
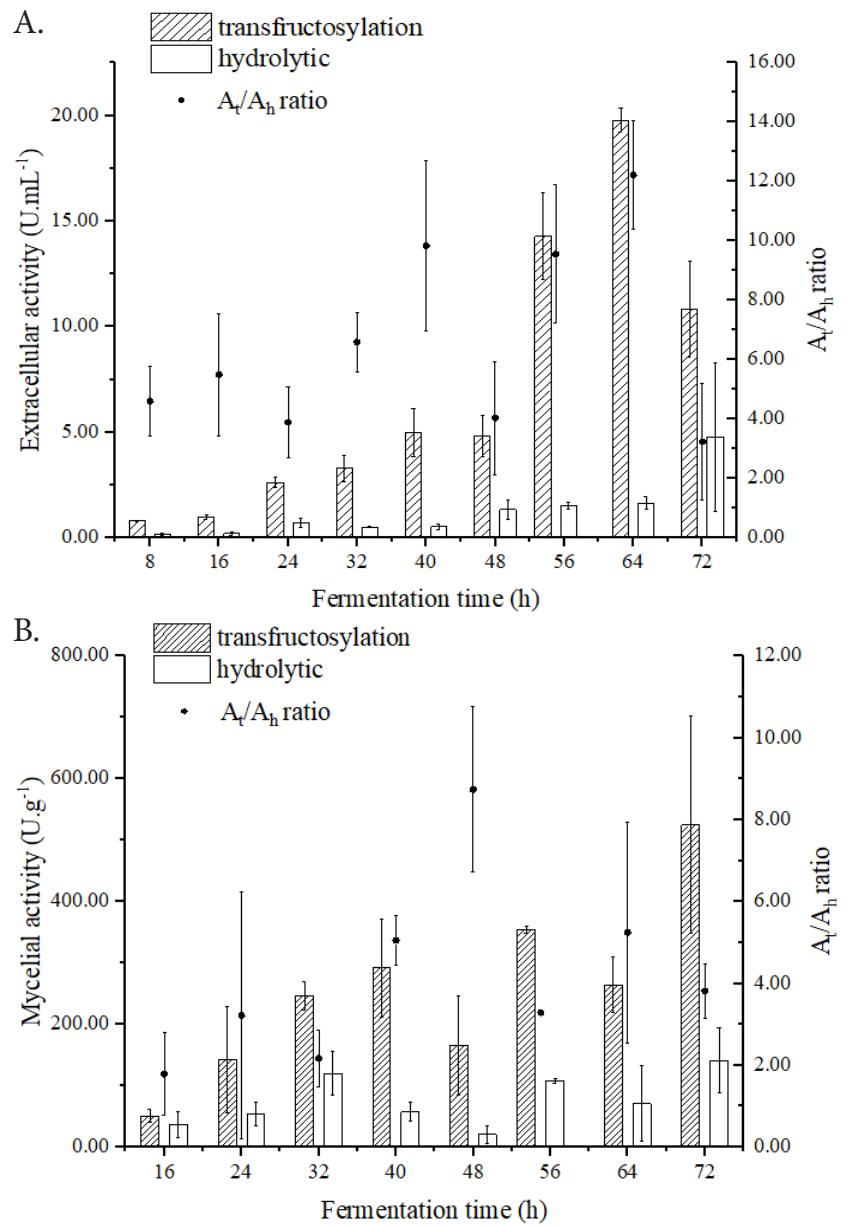

Figure 2. Influence of the fermentation time on the hydrolytic $\left(\mathrm{A}_{\mathrm{h}}\right)$ and transfructosylation $\left(\mathrm{A}_{t}\right)$ activities of extracellular (A) and mycelial (B) FTase and the ratio between the activities $\left(\mathrm{A} / \mathrm{A}_{\mathrm{b}}\right)$ in $47.06 \%(\mathrm{~m} / \mathrm{v})$ sucrose solution and $0.2 \mathrm{~mol} \mathrm{~L}^{-1}$ tris-acetate buffer, $\mathrm{pH}$ 5.5 at $50^{\circ} \mathrm{C}$. 
proteases, responsible for the cleavage of peptide bonds and release of amino acids, which causes acidification of the culture medium, also interfering with the enzymatic activities (Castro and Sato 2014; Tsujita et al., 1997). According to Ganaie and Gupta (2014), the highest productivity of FOS can be obtained in 36 $\mathrm{h}$ of fermentation when using the strains of the fungi A. niger and A. flavus. However, the authors point out that, when the production of FTase and FOS is carried out, a low sugar yield can be observed, since the production of biomass and, consequently, of enzyme occur in an optimal temperature range between $28^{\circ} \mathrm{C}$ to $30^{\circ} \mathrm{C}$, whereas the maximum FOS production can be checked for an optimum range of $50^{\circ} \mathrm{C}-60^{\circ} \mathrm{C}$.

\section{Effect of pH and temperature on stability enzymatic}

The stability of the extracellular FTase showed the highest relative transfructosylation activity at $\mathrm{pH}$ 6.0 (Fig.3A), whereas the mycelial FTase occurred
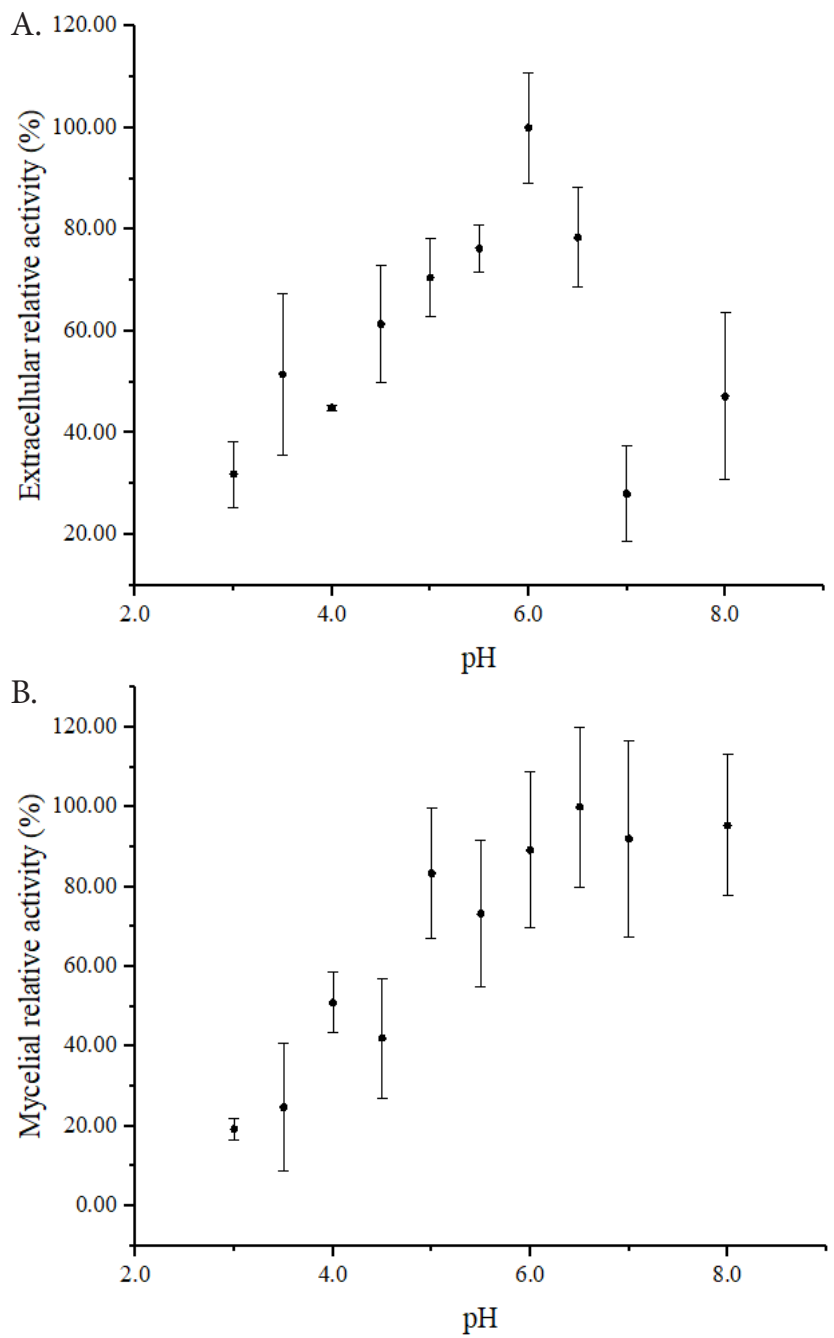

Figure 3. The stability of FTase-pH after $24 \mathrm{~h}$ of incubation in $0.2 \mathrm{~mol} \mathrm{~L}^{-1}$ tris-acetate buffer solution at $4{ }^{\circ} \mathrm{C}$. Activity of transfructosylation (A) extracellular at $100 \%\left(14.96 \pm 1.62 \mathrm{U} \mathrm{mL}^{-1}\right)$ and (B) mycelial at $100 \%\left(189.23 \pm 37.82 \mathrm{U} \mathrm{g}^{-1}\right)$. between pH 5.0 - 8.0 (Fig. 3B). Yang et al. (2016) using $A$. niger YZ59 recombinant expressed in $P$. pastoris GS115, detected the optimum $\mathrm{pH}$ of FTase at 5.5 and stability of the enzyme ranging from $\mathrm{pH} 3.0$ to 10.0. The work of Lateef et al. (2007) and Sangeetha et al. (2005) reported the stability of mycelial FTases produced by Aureobasidium pullulans CFR 77 and Aspergillus oryzae CFR 202 for ranges of $\mathrm{pH} 3.5$ 10.0 and $\mathrm{pH} 5.0-7.0$, respectively.

The thermal stability of the extracellular FTases (Fig. 4A) occurred only at temperatures below $35^{\circ} \mathrm{C}$, and attained at up to $96 \%$. At temperatures above $40{ }^{\circ} \mathrm{C}$, there was a marked decrease in activity, and only $44.26 \%$ of the initial activity was maintained at a temperature of $65{ }^{\circ} \mathrm{C}$. Xu et al. (2015) reported that the enzyme produced by Penicillium oxalicum was maintained with up to $80 \%$ of the initial $A_{t}$ for a temperature range between $25^{\circ} \mathrm{C}$ and $55^{\circ} \mathrm{C}$. Madlová et
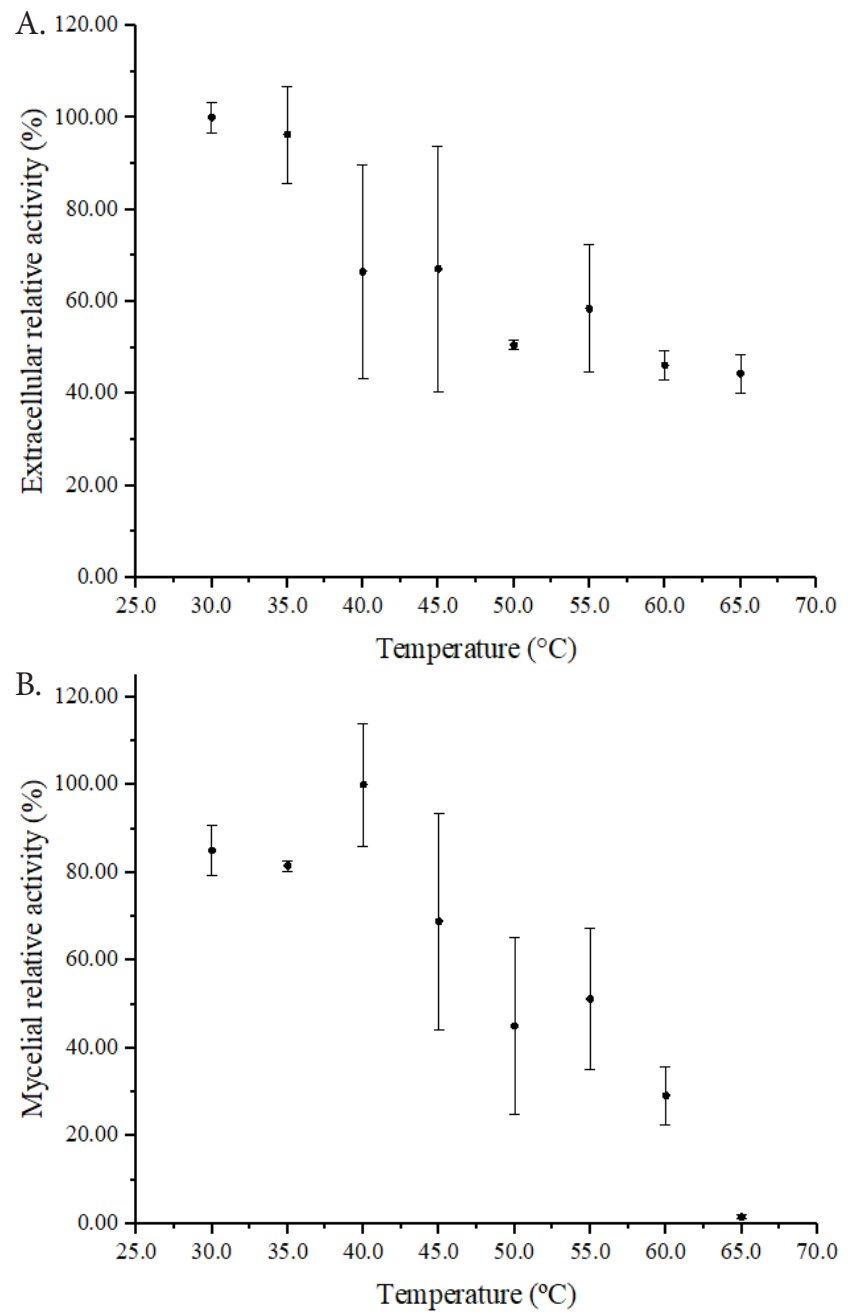

Figure 4. Thermal stability of the FTase evaluated at different temperatures a-post incubation for $1 \mathrm{~h}$ in $0.2 \mathrm{~mol} \mathrm{~L}^{-1}$ tris-acetate buffer $\mathrm{pH} 5.5$. Activity of transfructosylation (A) at $100 \%$ (A) extracellular $100 \%\left(22.65 \pm 0.72 \mathrm{U} \mathrm{mL}^{-1}\right)$ and (B) mycelial $100 \%$ $\left(418.56 \pm 58.44 \mathrm{U} \mathrm{g}^{-1}\right)$. 
al. (2000) demonstrated that FTases of Aureobasidium pullulans were rapidly inactivated when subjected to temperatures higher than $60{ }^{\circ} \mathrm{C}$, even in the presence of high substrate concentrations. Mycelial FTase (Fig. 4B) remained stable for a temperature range from $30^{\circ} \mathrm{C}$ and $40{ }^{\circ} \mathrm{C}$, where relative transfructosylation activities remained between $80 \%$ and $100 \%$. At temperatures above $45{ }^{\circ} \mathrm{C}$, a marked decrease in enzyme activity was observed until complete inactivation of the enzyme was achieved at $65^{\circ} \mathrm{C}$. Similar behavior has also been reported in Hayashi et al. (1990), in which the mycelial FTase of Aureobasidium sp. ATCC 20254 showed low thermal stability at temperatures above 50 ${ }^{\circ} \mathrm{C}$ until complete inactivation at $70{ }^{\circ} \mathrm{C}$ after $15 \mathrm{~min}$ incubation.

Effects of sucrose concentration in the reaction medium and determination of kinetic parameters

The sucrose concentration range of $296 \mathrm{~g} \mathrm{~L}^{-1}-592$ $\mathrm{g} \mathrm{L}^{-1}$ had an average value of $\mathrm{A}_{\mathrm{t}}$ equal to $14.58 \pm 0.09 \mathrm{U}$ $\mathrm{mL}^{-1}$. The extracellular FTase, produced by $A$. oryzae IPT-301, was satisfactorily adjusted to the MichaelisMenten kinetic model without being inhibited by the different concentrations of sucrose evaluated, with $\mathrm{R}^{2}$ $=0.991$ (Fig. 5A). The values of the kinetic parameters $\left(\mathrm{V}_{\text {máx }} 16.23 \mathrm{U} \mathrm{mL}^{-1}\right.$ and $\left.\mathrm{K}_{\mathrm{m}} 50.41 \mathrm{~g} \mathrm{~L}^{-1}\right)$ of the proposed model were obtained using the software Origin 8.0. Differently, Aguiar-Oliveira and Maugeri (2010) reported that, at substrate concentrations above $500 \mathrm{~g}$ $\mathrm{L}^{-1}$, inhibition occurs by the substrate, with adjustment by the classic michaelian model with inhibition. In this work, it was not possible to obtain the kinetic parameters that supported the hypothesis of such inhibition with the data obtained.

The substrate concentration effect on mycelial FTase activities were also investigated. Compared with the concentration effects of extracellular FTase, the enzyme showed higher sensitivity to the sucrose concentration in the reaction medium, with a maximum value of $A_{t} 282.57 \pm 27.33 \mathrm{U} \cdot \mathrm{g}^{-1}$ in $470.6 \mathrm{~g} \cdot \mathrm{L}^{-1}$ sucrose solution. The $\mathrm{A}_{\mathrm{b}}$ was maintained at an average value of $63.66 \pm 15.00 \mathrm{U} \cdot \mathrm{g}^{-1}$ for the whole sucrose concentration range evaluated. The enzymatic kinetics of the transfructosylation was evaluated following the Hill model (Fig. 5B), whose error determination coefficient value $\mathrm{R}^{2}=0.926$, indicating that this model accounts for $92.6 \%$ of the variations in mycelial transfructosylation rate, with the values of the kinetic parameters $\left(\mathrm{V}_{\text {mix }} 342.23 \mathrm{U}\right.$ $\left.\mathrm{g}^{-1}, \mathrm{~K}_{05} 234.73 \mathrm{~g} \mathrm{~L}^{-1}, n=1.41\right)$. The Michaelis-Menten model was also tested; however, the low value of the determination coefficient renders it invalid for the explanation of the transfrutosilation velocities (data not shown). Hernalsteens (2008) reported that the enzyme produced by the strain Rhodotorula sp. also
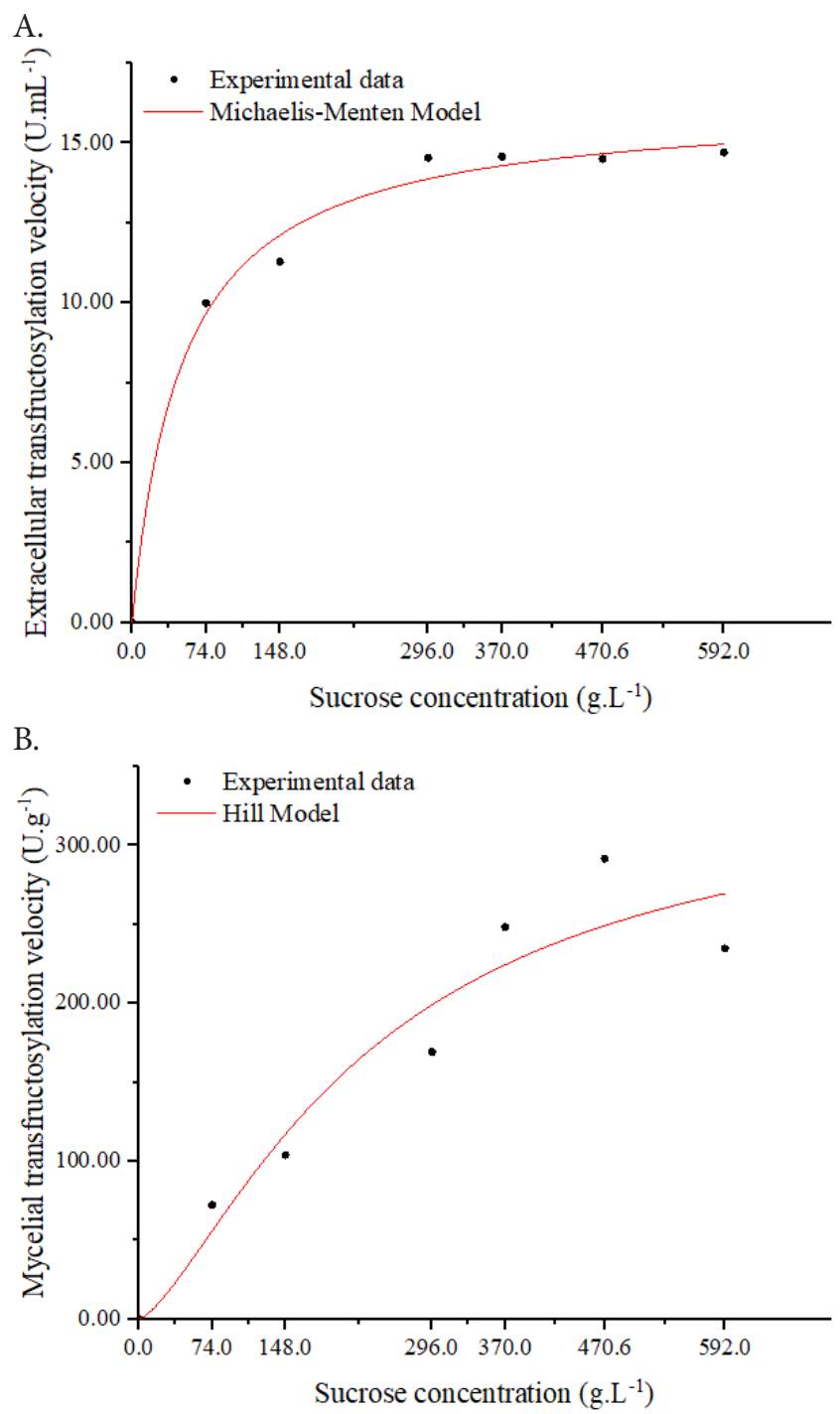

Figure 5. Michaelis-Menten model $\left(R^{2}=0.991\right)$ for extracellular (A) and Hill model $\left(R^{2}=0.926\right)$ for mycelial (B) FTase transfructosylation velocity at $50{ }^{\circ} \mathrm{C}$ and $0.2 \mathrm{~mol} \mathrm{~L}^{-1}$ tris-acetate buffer $\mathrm{pH} 5.5$, comparing theorical results with experimental results.

showed cooperative kinetics according to the Hill Model for the transfructosylation rate, with values of the parameters $\mathrm{V}_{\text {máx }}, \mathrm{Km}_{0.5}$ and $n$ of $299.0 \mathrm{~g} \cdot \mathrm{L}^{-1}, 0.08 \mathrm{~g}$ $\mathrm{L}^{-1}$ and 2.2 , respectively.

Comparing the mycelial and extracellular FTases, an expressive increase of the Michaelis-Menten $\left(\mathrm{K}_{\mathrm{m}}\right)$ constant of 4.7-fold was observed, indicating that the mycelial FTase exhibited lower affinity for the substrate. Hirayama et al. (1989) obtained values of $\mathrm{K}_{\mathrm{m}}$ equal to $99.18 \mathrm{~g} \mathrm{~L}^{-1}, 273.6 \mathrm{~g} \mathrm{~L}^{-1}, 47.9 \mathrm{~g} \mathrm{~L}^{-1}$ and $126.54 \mathrm{~g} \mathrm{~L}^{-1}$, for the enzyme purified from Aspergillus niger ATCC 20611 for the sugars sucrose, 1-kestose, nystose and fructosylnystose, respectively. Xu et al. (2015) obtained values of $\mathrm{K}_{\mathrm{m}}$ and $\mathrm{V}_{\text {maxx }}$ equal to $56.05 \mathrm{~g} \mathrm{~L}^{-1}$ and $800.1 \mathrm{U} \mathrm{mg}^{-1}$ for sucrose as substrate, respectively, for the purified FTase of Penicillum oxalicum. 
Optimization of enzymatic activities of extracelular and mycelial FTase with $\mathrm{pH}$ and temperature of the reaction medium

The factors and levels used, with coded and actual values, are listed in Table 1 . Their respective responses to the extracellular and mycelial transfructosylation $\left(A_{t}^{\text {extra }}, A_{t}^{\text {mycelial }}\right)$ and hydrolytic $\left(A_{h}{ }^{\text {extra }}, A_{h}{ }^{\text {mycelial }}\right)$ activities are shown in Table 2 . The responses were statistically analyzed and used to estimate the interaction effects with the quadratic model with interaction. According to the conditions used in the process, the $\mathrm{A}_{t}^{\text {extra }}$ values obtained varied from $\quad 3.75 \mathrm{U} \mathrm{mL}^{-1}$ to $15.85 \mathrm{U} \mathrm{mL}^{-}$ 1. The central points for the three responses presented low variation, indicating, therefore, good repeatability of the process. Regarding mycelial FTase, the $\mathrm{A}_{t}^{\text {mycelial }}$ ranged from $22.99 \mathrm{U} \cdot \mathrm{g}^{-1}$ to $333.88 \mathrm{U} \cdot \mathrm{g}^{-1}$, while the $\mathrm{A}_{\mathrm{h}}{ }^{\text {mycelial }}$ ranged from $28.63 \mathrm{U} \cdot \mathrm{g}^{-1}$ to $106.40 \mathrm{U} \cdot \mathrm{g}^{-1}$. The obtained mycelial responses were treated statistically and, subsequently, the effects of the temperature and $\mathrm{pH}$ of the reaction medium were quantified.

According to Table 3, all effects were significant for the quadratic model with interaction for the influence of temperature and $\mathrm{pH}$ of the enzymatic reaction medium on the extracellular FTase transfructosylation activity, at a significance level of $5 \%(p<0.05)$. The adjusted model was described by Equation (4), where $\mathrm{A}_{t}$ extra refers to extracellular $\mathrm{A}_{\mathrm{t}}\left(\mathrm{U} \cdot \mathrm{mL}^{-1}\right), \mathrm{T}$ and $\mathrm{pH}$ represent the coded values for temperature and $\mathrm{pH}$ of the enzymatic reaction medium, respectively.

$$
\begin{aligned}
\mathrm{A}_{\mathrm{t}}^{\mathrm{extra}} & =15.100+1.772 .(\mathrm{T})-2.591 .(\mathrm{pH})- \\
& -3.290 .(\mathrm{T})^{2}-4.297 .(\mathrm{pH})^{2}-2.702 .(\mathrm{pH}) .(\mathrm{T})
\end{aligned}
$$

The effects of temperature and $\mathrm{pH}$ of the reaction medium on the quantification of $\mathrm{A}_{\mathrm{b}}$ of extracellular FTase $\left(\mathrm{A}_{\mathrm{h}}{ }^{\text {extra }}\right)$ were also evaluated. According to the conditions used in the process (Table 1), $A_{h}{ }^{\text {extra }}$ values ranged from $0.65 \mathrm{U} \mathrm{mL}^{-1}$ to $10.15 \mathrm{U} \mathrm{mL}^{-1}$, with very close values at the central points, representing good repeatability of the process. As shown in Table 3, the linear $\mathrm{pH}$ term ( $\mathrm{pH}(\mathrm{L})$, in bold) was not significant and therefore excluded from the quadratic model with interaction (Equation 5). In the equation, $A_{h}$ extra refers to extracellular $A_{h}\left(\mathrm{U} \mathrm{mL}^{-1}\right)$ and $T$ and $\mathrm{pH}$ represent the coded values for temperature and $\mathrm{pH}$, respectively.

$$
\begin{aligned}
\mathrm{A}_{\mathrm{h}}^{\mathrm{extra}} & =0.793-1.573 \cdot(\mathrm{T})+3 \cdot 132 .(\mathrm{T})^{2}+ \\
& +2.727 \cdot(\mathrm{pH})^{2}+2.045 \cdot(\mathrm{pH}) \cdot(\mathrm{T})
\end{aligned}
$$

\begin{tabular}{|c|c|c|c|c|c|}
\hline \multicolumn{2}{|c|}{ Factors } & \multicolumn{2}{|c|}{ Extracellular activities } & \multicolumn{2}{|c|}{ Mycelial activities } \\
\hline \multirow{2}{*}{$\begin{array}{c}\text { Temperature } \\
\left({ }^{\circ} \mathrm{C}\right)\end{array}$} & \multirow{2}{*}{ pH } & $\mathbf{A}_{\mathrm{t}}^{\text {extra }}$ & $\mathbf{A}_{h}{ }^{\text {extra }}$ & $\mathbf{A}_{\mathbf{t}}^{\text {mycelial }}$ & $\mathbf{A}_{\mathrm{h}}{ }^{\text {mycelial }}$ \\
\hline & & \multicolumn{2}{|c|}{$\left(\mathrm{U} \mathrm{mL}^{-1}\right)$} & \multicolumn{2}{|c|}{$\left(\mathrm{U} \mathrm{g}^{-1}\right)$} \\
\hline$-1(40)$ & $-1(5.5)$ & 4.32 & 8.29 & 82.62 & 106.40 \\
\hline $1(50)$ & $-1(5.5)$ & 15.86 & 1.08 & 333.88 & 81.17 \\
\hline$-1(40)$ & $1(8.0)$ & 3.80 & 6.44 & 142.39 & 44.00 \\
\hline $1(50)$ & $1(8.0)$ & 4.53 & 7.41 & 22.99 & 31.98 \\
\hline$-1.414(38)$ & $0(6.75)$ & 8.23 & 10.15 & 31.59 & 28.63 \\
\hline $1.414(52)$ & $0(6.75)$ & 9.58 & 5.66 & 222.16 & 40.45 \\
\hline $0(45)$ & $-1.414(5.0)$ & 10.03 & 6.91 & 128.99 & 67.91 \\
\hline $0(45)$ & $1.414(8.5)$ & 3.75 & 7.28 & 39.22 & 42.03 \\
\hline $0(45)$ & $0(6.75)$ & 14.74 & 1.02 & 214.50 & 58.63 \\
\hline $0(45)$ & $0(6.75)$ & 14.72 & 0.65 & 193.02 & 40.68 \\
\hline $0(45)$ & $0(6.75)$ & 15.84 & 0.71 & 202.58 & 31.11 \\
\hline
\end{tabular}

Table 2. Levels of factors used in the experimental design and corresponding experimental values.

Table 3. Estimated effects, standard error and p-value for the evaluation of temperature and pH effects on extracellular FTase transfructosylation and hydrolytic activities.

\begin{tabular}{ccc}
\hline Variables & Estimated effects & Standard error \\
\hline & Transfructosylation activity- Extracellular FTase & 1.049679 \\
Mean & 15.10000 & 1.285589 \\
Temperature (L) & 3.54480 & 1.530156 \\
Temperature (Q) & -6.58000 & 1.285589 \\
pH (L) & -5.18282 & 1.530156 \\
pH (Q) & -8.59500 & 0.000029 \\
pH x temperature & -5.40500 & 0.007714 \\
Mean & Hydrolytic activity- Extracellular FTase & 0.010007 \\
Temperature (L) & 0.79333 & 0.720342 \\
Temperature (Q) & -3.14745 & 0.882236 \\
pH (L) & 6.26417 & 1.050071 \\
pH (Q) & 1.25081 & 0.031053 \\
pH x temperature & 5.45417 & 0.882236 \\
\end{tabular}


According to Rodrigues and Iemma (2009), the application of the $\mathrm{F}$ test to the model explains a significant amount of variation of the experimental data. The value of $F$, calculated by Equation (6), is compared with the tabulated value of a reference frequency distribution $\left(\mathrm{F}_{\mathrm{G}}\right.$ deviation; level of significance).

Test $\mathrm{F}=\frac{\text { Regression mean squares }}{\text { Residual mean squares }}$

In Table 4, the analysis of variance (ANOVA) is presented for the quadratic model with interaction applied for the transfructosylation and hydrolytic activities of extracellular FTase. The adequacy of the model was evaluated using the determination coefficient $\left(\mathrm{R}^{2}\right)$. For the transfructosylation activity, approximately $93.48 \%$ of the variability of the observed responses can be explained by the adjusted model (Equation 4). As the coefficient of variation was high and the tabulated value of $\mathrm{F}$ for $95 \%$ confidence is 5.05, inferior to the 14.303 obtained with the model, it was possible to affirm that the amount of variation due to the model was greater than the variation not explained, therefore, the model was considered valid.

The analysis of variance (ANOVA) was presented for the quadratic model with interaction applied for the hydrolytic activity of extracellular FTase (Table 4). The adjustment of the experimental responses to the model was evaluated by the coefficient of determination of error $\left(\mathrm{R}^{2}\right)$ and the $\mathrm{F}$ Test. It was observed that the coefficient of variation explained $\left(\mathrm{R}^{2}=0.9112\right)$ was high.

The results obtained by means of the response surface for the extracellular transfructosylation activity (Figure 6A) and its contour curves (Figure

Table 4. Results of the analysis of variance for the quadratic model with interaction for the evaluation of the temperature and $\mathrm{pH}$ effects of the enzymatic reaction medium in the transfructosylation and hydrolytic activities for the extracellular FTase.

\begin{tabular}{ccccc}
\hline Source & $\begin{array}{c}\text { Sum of } \\
\text { Squares }\end{array}$ & $\begin{array}{c}\text { Degree of } \\
\text { Freedom }\end{array}$ & $\begin{array}{c}\text { Mean } \\
\text { Square }\end{array}$ & F value \\
\hline Transfructosylation activity - Extracellular FTase \\
Model & 237.649 & 5 & 47.53 & 14.303 \\
Residues & 16.6146 & 5 & 3.32 & \\
Lack of Fit & 15.7058 & 3 & & \\
Pure Error & 0.8216 & 2 & & \\
Total & 254.2636 & 10 & \\
$\mathrm{R}^{2}=0.93482$ & $\mathrm{~F} 5 ; 5 ; 0,05$ & 5.05 & \\
\hline \multicolumn{5}{c}{ Hydrolytic activity- Extracellular FTase } \\
Model & 112.0986 & 4 & 28.02 & 15.408 \\
Residue & 10.9125 & 6 & 1.82 & \\
Lack of Fit & 10.8336 & 4 & \\
Pure Error & 0.0789 & 2 & \\
Total & 123.0111 & 10 & \\
$\mathrm{R}^{2}=0.9112$ & $\mathrm{~F}_{4 ; 6 ; 0,05}=4.53$ &
\end{tabular}

A.

B.
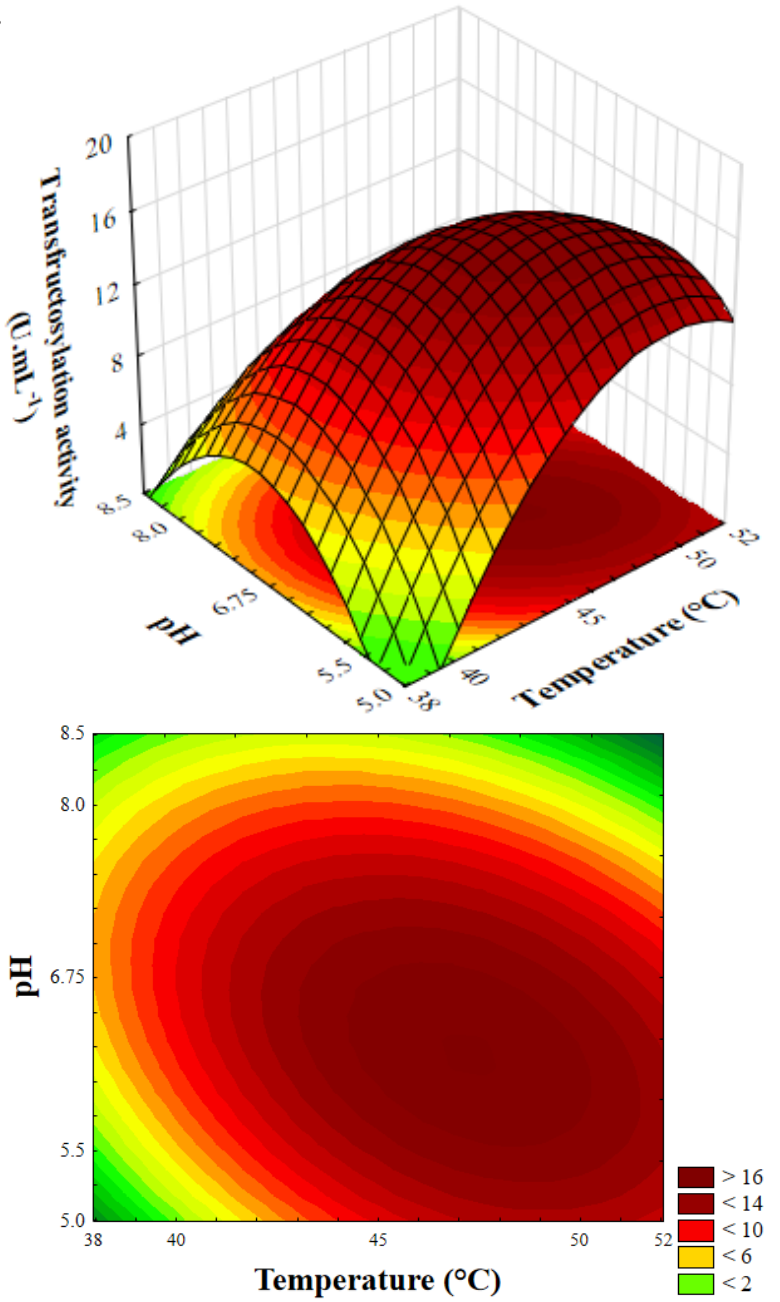

Figure 6. Response surface for the extracellular transfructosylation activity as a function of the $\mathrm{pH}$ and temperature of the enzymatic reaction medium (A); Contour curves for the extracellular transfructosylation activity as a function of the $\mathrm{pH}$ and temperature of the enzymatic reaction medium (B).

6B) show an optimal zone between the temperatures of $45{ }^{\circ} \mathrm{C}$ and $50{ }^{\circ} \mathrm{C}$ and $\mathrm{pH}$ between 5.5 and 6.75 . It should be emphasized that the results obtained by the experimental design consistently described the behavior of the enzymatic activities when evaluated, alone, under the influence of $\mathrm{pH}$ and temperature. While the present results indicated that the increases in temperature and $\mathrm{pH}$ of the reaction medium were significant, Cuervo-Fernandez et al. (2007) reported that, for the same $\mathrm{pH}$ and temperature ranges, only the increase in $\mathrm{pH}$ (5.5 to 8.0) was significant in the optimization studies, resulting in significant gains in transfructosylation activities.

The developed model was represented by a response surface for the extracellular hydroliytic activity (Figure 7A) and the contour curves (Figure $7 \mathrm{~B}$ ), in order to analyze the interactions between the two dependent variables in the response and to obtain 
A.

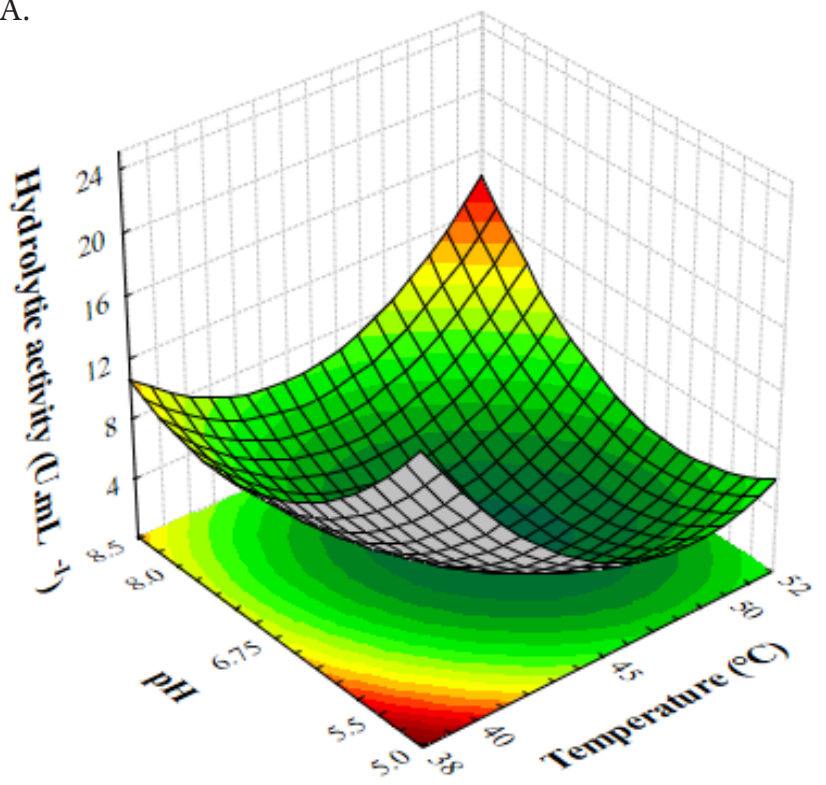

B

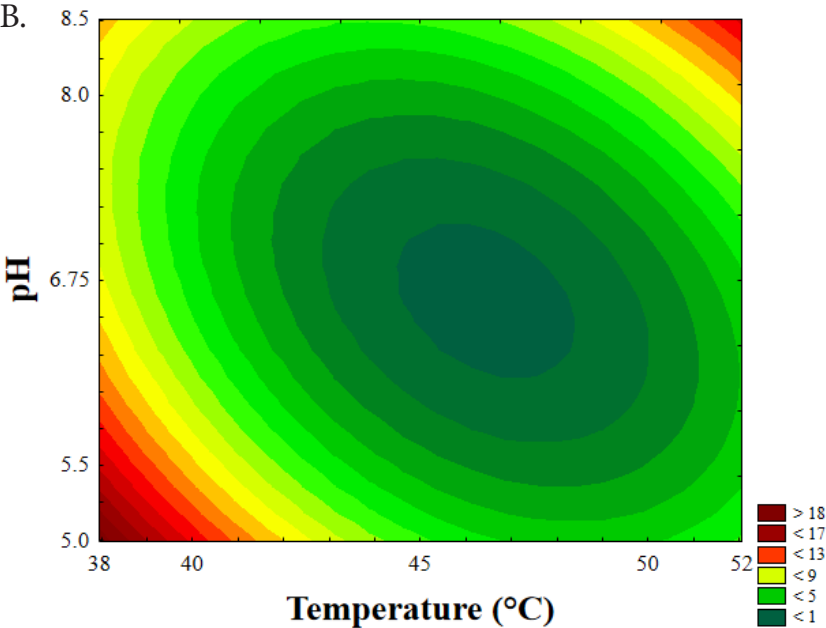

Figure 7.Response surface for extracellular hydrolytic activity as a function of $\mathrm{pH}$ and temperature of the enzymatic reaction medium (A); Contour curves for the extracellular hydrolytic activity as a function of $\mathrm{pH}$ and temperature of the reaction medium (B).

an optimal zone, where low $A_{h}$ values are achieved. These low $\mathrm{A}_{\mathrm{b}}$ values consequently result in high FOS production due to the impaired cleavage of sugar molecules with a high degree of polymerization. From the surfaces and curves obtained, the formation of an optimum zone between the temperatures of $45^{\circ} \mathrm{C}$ and $48^{\circ} \mathrm{C}$ and $\mathrm{pH}$ between 6.0 and 7.0 was observed.

The effects of temperature and $\mathrm{pH}$ of the reaction medium on the quantification of enzymatic activities of mycelial FTase $\left(A_{t}^{\text {mycelial }}\right.$ and $A_{h}$ mycelial $)$ were also evaluated. For the transfructosylation activity, the effects of the regression components (Table 5) and, in the $95 \%$ confidence interval $(\mathrm{p}<0.05)$, all were significant except the quadratic temperature term (temperature (Q), in bold). The adjusted model was described by Equation 7, where $A_{t}^{\text {mycelial }}$ refers to mycelial $\mathrm{A}_{t}\left(\mathrm{U} \cdot \mathrm{g}^{-1}\right), \mathrm{T}$ and $\mathrm{pH}$ represent the coded values for temperature and $\mathrm{pH}$ of the enzymatic reaction medium, respectively.

$$
\begin{aligned}
\mathrm{A}_{\mathrm{t}}^{\text {mycelial }} & =203,366+50,170 \cdot(\mathrm{T})-28,250 \cdot(\mathrm{T})^{2}- \\
& -47,259 \cdot(\mathrm{pH})-49,635 \cdot(\mathrm{pH})^{2}-92,665 \cdot(\mathrm{pH}) \cdot(\mathrm{T})
\end{aligned}
$$

Regarding hydrolytic activity, the high variation of the $A_{b}$ mycelial values obtained, even at the central points where a good repetition was expected in order to reduce errors, directly reflected the calculated effects and their respective significance, in which none of the calculated terms except the mean (bold in Table 5 ), were significant at a significance level of $5.0 \%$. Thus, it was not possible to generate a model that explains the variation of mycelial hydrolytic activity as a function of $\mathrm{pH}$ and temperature of the enzymatic reaction medium.

The analysis of variance (ANOVA) of the quadratic model with interaction applied to the $A_{t}^{\text {mycelial }}$ as a function of the temperature and $\mathrm{pH}$ of the reaction medium (Table 6) presented the tabulated value of $\mathrm{F}$ for $95 \%$ confidence of 5.05, inferior to the 11.317 obtained with the model. Another parameter analyzed was the coefficient of variation $\left(\mathrm{R}^{2}\right)$, whose value was equal to 0.9187 , stating that $91.87 \%$ of the total variation for the enzymatic activity response was due to the attribution of the mathematical model.

The results of the analysis of variance (ANOVA) showed that the quadratic model with interaction (Equation 7) was adequate for the prediction of $\mathrm{A}_{t}^{\text {mycelial }}$, represented by the response surface (Figure $8 \mathrm{~A}$ ) as well as the respective contour curves (Figure $8 \mathrm{~B}$ ). The high values of $\mathrm{A}_{t}^{\text {mycelial }}$ (values greater than $260.00 \mathrm{U} \cdot \mathrm{g}^{-1}$ ) were detected in acid regions below pH 6.5 and at temperatures above $46{ }^{\circ} \mathrm{C}$. The

Table 5. Estimated effects, standard error and p-value for evaluation of temperature and $\mathrm{pH}$ effects on the transfructosylation and hydrolytic activities of

\begin{tabular}{|c|c|c|c|}
\hline Variable & $\begin{array}{c}\text { Estimated } \\
\text { effects }\end{array}$ & $\begin{array}{c}\text { Standard } \\
\text { Error }\end{array}$ & p-value \\
\hline \multicolumn{4}{|c|}{ Transfructosylation activity-Mycelial FTase } \\
\hline Mean & 203.367 & 22.69200 & 0.000288 \\
\hline temperature $(\mathrm{L})$ & 100.342 & 27.79191 & 0.015373 \\
\hline tempera & -56 & 33. & \\
\hline $\mathrm{pH}$ & -94 & 27. & 0. \\
\hline $\mathrm{pH}$ & -99. & 33. & 0. \\
\hline $\mathrm{pH} x$ temperature & -185.330 & 39.30369 & \\
\hline \multicolumn{4}{|c|}{ Hydrolytic activity-Mycelial FTase } \\
\hline Mean & 43.4676 & 12.51806 & 0.017795 \\
\hline temperature $(\mathrm{L})$ & -5.13 & 15.33143 & 0.7 \\
\hline temperature $(\mathrm{Q})$ & 1.6398 & 18.24805 & 0.932171 \\
\hline $\mathrm{pH}(\mathrm{L})$ & -37.0511 & 15.33143 & 0.060382 \\
\hline $\mathrm{pH}(\mathrm{Q})$ & 22.0743 & 18.24805 & 0.280689 \\
\hline $\mathrm{pH} x$ temperature & 6.6017 & 21.68191 & 0.772918 \\
\hline
\end{tabular}
mycelial FTase. 
Table 6. Results of the ANOVA for the quadratic model with interaction described by the effects of temperature and $\mathrm{pH}$ on the transfructosylation activity of mycelial FTase.

\begin{tabular}{ccccc}
\hline Source & $\begin{array}{c}\text { Sum of } \\
\text { Squares }\end{array}$ & $\begin{array}{c}\text { Degree of } \\
\text { Freedom }\end{array}$ & $\begin{array}{c}\text { Mean } \\
\text { Square }\end{array}$ & $\mathbf{F}_{\text {value }}$ \\
\hline \multicolumn{5}{c}{ Transfructosylation } \\
Modivity-Mycelial FTase & \\
Residues & 87414.47 & 5 & 17482.89 & 11.317 \\
Lack of Fit & 7723.90 & 5 & 1544.78 & \\
Pure Error & 7492.28 & 3 & & \\
Total & 231.62 & 2 & & \\
$\mathrm{R}^{2}=0.9187$ & $\mathrm{~F}_{5 ; 5 ; 0,05}=5.05$ & 10 & & \\
\hline
\end{tabular}

A.

B.
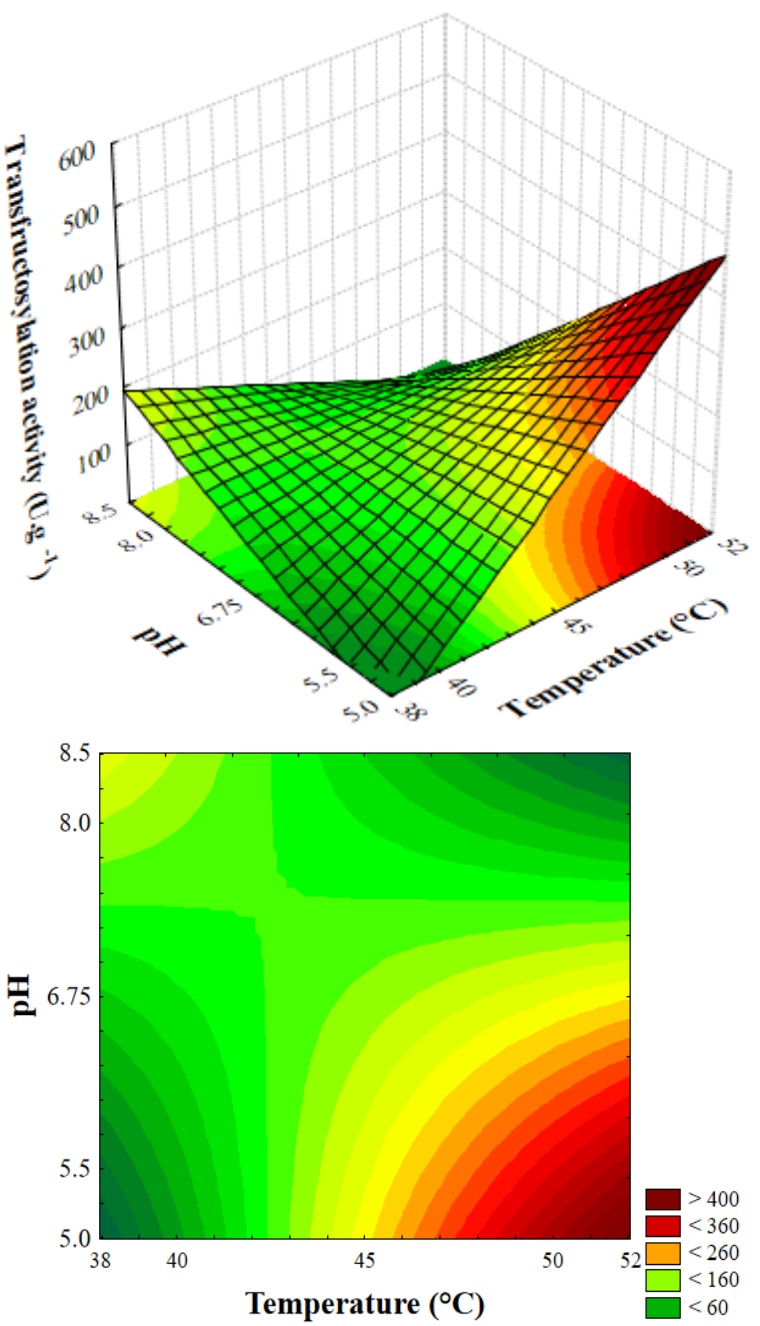

Figure 8. Response surface for the mycelial transfructosylation activity as a function of $\mathrm{pH}$ and temperature of the reaction medium (A); Contour curves for mycelial transfructosylation activity as a function of $\mathrm{pH}$ and temperature of the reaction medium (B).

behavior of mycelial FTase indicated the highest $\mathrm{pH}$ and temperature ranges because of greater stability due to the adhesion of the enzyme to the mycelium (Schuurmann et al., 2014).

\section{CONCLUSIONS}

Aspergillus oryzae IPT-301 showed maximum concentration of cellular biomass, $9.35 \pm 1.26 \mathrm{~g} \mathrm{~L}^{-1}$, in $48 \mathrm{~h}$ fermentation time. Extracellular FTase showed maximum $\mathrm{A}_{t}$ when produced in $64 \mathrm{~h}$ of fermentation and it presented stability above $80 \%$ between 30 ${ }^{\circ} \mathrm{C}$ and $35{ }^{\circ} \mathrm{C}$ and at $\mathrm{pH}$ 6.0. While the maximum mycelial FTase activity occurred in $72 \mathrm{~h}$, indicating stability above $80 \%$ for $\mathrm{pH}$ ranges $(6.0-8.0)$ and temperature $\left(30-40{ }^{\circ} \mathrm{C}\right)$. The extracellular FTase showed michaelian kinetics in relation to the substrate concentration, while mycelial FTase adjusted to Hill's cooperative model. Regarding the optimization of reactional parameters for high enzymatic activities, it was proved that the optimal zone of the extracellular FTase occurred in the temperature ranges between 45 ${ }^{\circ} \mathrm{C}-50{ }^{\circ} \mathrm{C}$ and $\mathrm{pH}$ between $5.5-6.75$, large enough to resist the occurence of variation of the process parameters and keep high values of transfructosylation and low hydrolytic activities. As for mycelial FTase, the optimal zone for transfructosylation activity occurred at temperatures above $46^{\circ} \mathrm{C}$ and at $\mathrm{pH}$ values lower than 6.5. These results will lead future research conducted on bioreactors to scale up and optimize the production of FTase on a larger scale aiming at high FOS production.

\section{ACKNOWLEDGEMENTS}

The authors gratefully acknowledge The State of Minas Gerais Research Foundation (FAPEMIG, Process APQ-02131-14) for providing financial support and the Institute for Technological Research (IPT/ SP)/Programa Novos Talentos, through an individual research grant attributed to Cristiane Angélica Ottoni.

\section{REFERENCES}

Ademakinwa, A.N., Ayinla, Z.N., Agboola, F.K. Strain improvement and statistical optimization as a combined strategy for improving fructosyltransferase production by Aureobasidium pullulans NAC8. J. Gen. Eng. Biotechnol., 15, 345-358 (2017). https://doi.org/10.1016/j. jgeb.2017.06.012

Aguiar-Oliveira, E., Maugeri, F. Characterization of the immobilized fructosyltranferase from Rhodotorula sp. Int. J. Food Eng., 6, (2010). https:// doi.org/10.2202/1556-3758.1894

Castro, R.J.S., Sato, H.H., Protease form Aspergillus oryzae: Biochemical characterization and application as a potential biocatalyst for production of protein hydrolases with antioxidant activities. J. Food Process., 2014, 1-11 (2014). http://dx.doi. org $/ 10.1155 / 2014 / 372352$ 
Cuervo-Fernandez, R., Maresma, B.G., Juárez, A., Martínez, J. Production of fructoligosaccharides by $\beta$-fructofuranosidase from Aspergillus sp. $27 \mathrm{H}$. ग. Chem. Technol. Biotechnol., 79, 268-272 (2004). https://doi.org/10.1002/jctb.967

Cuervo-Fernandez, R., Ottoni, C.A., Silva, E.S., Matsubara, R.M.S., Carter, J.M., Magossi, L.R., Wada, M.A., Andrade, M.F., Maresma, B.G., Maiorano, A.E. Screening of $\beta$-fructofuranosidaseproducing microorganisms and effect of $\mathrm{pH}$ and temperature on enzymatic rate. ^Appl. Microbiol. Biotechnol., 74, 87-93 (2007). https://doi. org/10.1007/s00253-006-0803-x

Chen, W.C., Liu, C.H., Production of $\beta$-fructofuranosidase by Aspergillus japonicus. Enzyme Micro. Tech., 18, 153-160 (1996). https:// doi.org/10.1016/0141-0229(95)00099-2

Farid, M.A-F.M., Kamel, Z., Elsayed, E.A., El-Deen, A.M.N. Optimization of medium composition and cultivation parameters for fructosyltransferase production by Penicillium aurantiogriseum AUMC 5605. J.Appl. Biol. Chem., 58, 209-218 (2015). https://doi.org/10.3839/jabc.2015.033

Ganaie, M.A., Soni, H., Naikoo, G.A., Oliveira, L.T.S., Rawat, H.K., Mehta, P.K., Narain, N. Screening of low cost agricultural wastes to maximize the fructosyltransferase production and its applicability in generation of fructooligosaccharides by solid state fermentation. Int. Biodeterior. Biodegradation, 118, 19-26 (2017). https://doi.org/10.1016/j. ibiod.2017.01.006

Ganaie, M.A., Gupta, U.S. Recycling of cell culture and efficientrelease of intracelular fructosyltransferase by ultrasonication for the production of fructooligosaccharides. Carbohydr. Polym., 110, 253-258 (2014). https://doi.org/10.1016/j. carbpol.2014.03.066

Gujar, V.V., Fuke, P., Khardenavis, A.A., Purohit, H.J. Annotation and De Novo sequence characterization of extracellular $\beta$-fructofuranosidase from Penicillium chrysogenum strain HKF42. Indian J. Microbiol., 58, 227-233 (2018). https://doi. org/10.1007/s12088-017-0704-y

Guo, W., Yang, H., Qiang, S., Fan, Y., Shen, W., Chen, $\mathrm{X}$. Overproduction, purification, and property analysis of na extracellular recombinant fructosyltransferase. Eur Food Res. Technol., 242, 1159-1168 (2016). https://doi.org/10.1007/s00217015-2620-x

Hayashi, S., Nonokuchi, M., Imada, K., Ueno, H. Production of a fructosyl-transferring enzyme by Aureobasidium sp. ATCC 20524. J. Ind. Microbiol., 5, 395-400 (1990). https://doi.org/10.1007/ BF01578099

Hernalsteens, S., Maugeri, F. Purification and characterisation of a fructosyltransferase from Rhodotorula sp. App. Microbiol. and Biotechnol.,
79, 589-596 (2008). https://doi.org/10.1007/ s00253-008-1470-x

Hernández, L., Menéndez, C., Pérez, E.R., Martínez, D., Alfonso, D., Trujillo, L.E., Ramírez, R., Sobrino, A., Mazola, Y., Musacchio, A., Pimentel, E. Fructooligosaccharides production by Schedonorus arundinaceus sucrose:sucrose 1-fructosyltransferase constitutively expressed to high levels in Pichia pastoris. J. Biotech., 266, 59-71 (2017). https://doi.org/10.1016/j. jbiotec.2017.12.008

Hidaka, H., Hirayama, M., Sumi, N. A fructooligosaccharide producing enzyme from Aspergillus niger ATCC 20611. Agric. Biol. Chem., 52, 1181-1187 (1988). https://doi.org/10.1271/ bbb1961.52.1181

Hirayama, M., Sumi, N., Hidaka, H., Purification and properties of a fructooligosaccharide-producing $\beta$-fructofuranosidase from Aspergillus niger ATCC 20611. Agric. Biol. Chem., 53, 667-673 (1989). https://doi.org/10.1271/bbb1961.53.667

Huang, M.-P., Wu, M., Xu, Q.-S., Mo, D.-J., Feng, J.-X. Highly efficient synthesis of fructooligosaccharides by extracellular fructooligosaccharide-producing enzymes and immobilized cells of Aspergillus aculeatus M105 and purification and biochemical characterization of a fructosyltransferase from the fungus. J. Agric. Food Chem., 64, 6425-6432 (2016). https://doi.org/10.1021/acs.jafc.6b02115

Jitonnom, J., Ketudat-Cairns, J.R., Hannongbua, S. QM/MM modeling of the hydrolysis and transfructosylation reactions of fructosyltransferase from Aspergillus japonicas, an enzyme that produces prebiotic fructooligosaccharide. J. Mol. Graph. Model., 79, 175-184 (2018). https://doi. org/10.1016/j.jmgm.2017.11.010

Lateef, A., Oloke, J.K., Prapulla, S.G. The effect of ultrasonication on the release of fructosyltransferase from Aureobasidium pullulans CFR 77. Enzyme Microb. Technol., 40, 1067-1070 (2007). https:// doi.org/10.1016/j.enzmictec.2006.08.008

Lateef, A., Oloke, J.K., Gueguim-Kana, E.B., Oyeniyi, S.O., Onifade, O.R., Oyeleye, A.O., Olados, O.C. Rhizopus stolonifer LAU 07: a novel source of fructosyltransferase. Chem. Papers, 62, 635-638 (2008). https://doi.org/10.2478/s11696-008-0074-3

Lateef, A., Oloke, J.K., Gueguim-Kana, E., Raimi, O. Production of fructosyltransferase by a local isolate of Aspergillus niger in both submerged and solid substrate media. Acta Alimentaria, 41, 100-117 (2012). https://doi.org/10.1556/ AAlim.41.2012.1.12

Madlová, A., Antošová, M., Polakovič, M., Báleš, V. Thermal stability of fructosyltransferase from Aureobasidium pullulans. Chem. Papers., 54, 339344 (2000). 
Maiorano, A.E., Silva, E.S., Piccoli, R.S., Ottoni, C.A., Guillarte, B., Cuervo, R., Moreira, R., Rodrigues, M.F.D.A. Influence of the culture medium on the fructosyltransferase production. New Biotechnology, 25, S201 (2009). https://doi. org/10.1016/j.nbt.2009.06.137

Maiorano, A.E., Piccolli, R.S., Silva, E.S., Rodrigues, M.F.D.A., Microbial production of fructosyltransferases for synthesis of pre-biotics. Biotechnol. Letters, 30, 1867-1877 (2008). https:// doi.org/10.1007/s10529-008-9793-3

Mano, M.C.R., Neri-Numa, I.A., Silva, J.B. da, Paulino, B.N., Pessoa, M.G., Pastore, G.M. Oligosaccharide biotechnology: an approach of prebiotic revolution on the industry. Appl. Microbiol. Biotechnol., 102, 17-37 (2018). https://doi.org/10.1007/s00253-0178564-2

Miller, G.L. Use of dinitrosalicylic acid reagent for determination of reducing sugar. Analyt. Chem., 31, 426-428 (1959). https://doi.org/10.1021/ ac60147a030

Muñiz-Márquez, D.B., Contreras, J.C., Rodríguez, R., Mussatto, S.I., Teixeira, J.A., Aguilar, C.N. Enhancement of fructosyltransferase and fructooligosaccharides production by $A$. oryzae DIA-MF in solid-state fermentation using aguamiel as culture medium. Bioresour. Technol., 213, 276-282 (2016) https://doi.org/10.1016/j. biortech.2016.03.022

Nascimento, A.K.C., Nobre, C., Cavalcanti, M.T.H., Teixeira, J.A., Porto, A.L.F. Screening of fungi from the genus Penicillium for production of $\_\beta$ fructofuranosidase and enzymatic synthesis of fructooligosaccharides. J. Mol. Catal. B Enzym., 134, 70-78 (2016). https://doi.org/10.1016/j. molcatb.2016.09.005

Nobre, C., Alves Filho, E.G., Fernandes, F.A.N., Brito, E.S., Rodrigues, S., Teixeira, J.A., Rodrigues, L.R. Production offructo-oligosaccharides by Aspergillus ibericus and their chemical characterization. LWT - Food Sci. Technol., 89, 58-64 (2018). https://doi. org/10.1016/j.lwt.2017.10.015

Ottoni, C.A., Cuervo-Fernández, R., Piccoli, R.M., Moreira, R., Guilarte-Maresma, B., Sabino, E.S., Rodrigues, M.F.D.A., Maiorano, A.E. Media optimization for $\beta$-fructofuranosidase production by Aspergillus oryzae. Braz. J. Chem. Eng., 29,
49-59 (2012). https://doi.org/10.1590/S010466322012000100006

Perna, R.F., Cunha, J.S., Gonçalves, M.C.P., Basso, R.C., Silva, E.S., Maiorano, A.E. Microbial fructosyltransferase: production by submerged fermentation and evaluation of $\mathrm{pH}$ and temperature effects on transfructosylation and hydrolytic enzymatic activities. Int. J. Eng. Res.Sci., 4, 43-50 (2018).

Rodrigues, M.I., Iemma, A.F. Planejamento de experimentos \& otimização de processos. 2. ed. Campinas: Casa do Espírito Amigo Fraternidade Fé e Amor (2009).

Sangeetha, P.T., Ramesh, M.N., Prapulla, S.G. Fructooligosaccharide production using fructosyltransferase obtained from recycling culture of Aspergillus oryzae CFR 202. Process Biochem., 40, 1085-1088 (2005). https://doi.org/10.1016/j. procbio.2004.03.009

Schuurmann, J., Quehl, P., Festel, G., Jose, J. Bacterial whole-cell biocatalysts by surface display of enzymes toward industrial application. Appl. Microbiol. Biotechnol., 98, 8031-8046 (2014). https://doi.org/10.1007/s00253-014-5897-y

Tsujita, Y., Endo, A. Extracellular acid protease of Aspergillus oryzae grown on liquid media: multiple forms dua association with heterogeneous polysaccharides. J. Bacteriol., 130, 48-56 (1977).

Xu, Q., Zheng, X., Huang, M., Wu, M., Yan, Y., Pan, J., Yang, Q., Duan, C.-J., Liu, J.-L., Feng, J.-X. Purification and biochemical characterization of a novelfructofuranosidase from Penicillium oxalicum with transfructosylating activity producing neokestose. Process Biochem., 50, 1237-1246 (2015). https://doi.org/10.1016/j. procbio.2015.04.020

Yang, H., Wang, Y., Zhang, L., Shen, W. Heterologous expression and enzymatic characterization of fructosyltransferase from Aspergillus niger in Pichia pastoris. New Biotechnol., 33, 164-170 (2016). https://doi.org/10.1016/j.nbt.2015.04.005

Zhang, J., Liu, C., Xie, Y., Li, N., Ning, Z., Du, N., Huang, X., Zhong, Y. Enhancing fructooligosaccharides production by genetic improvement of the industrial fungus Aspergillus niger ATCC 2061. J. Biotechnol., 249, 25-33 (2017). https://doi. org/10.1016/j.jbiotec.2017.03.021 